\title{
Analisis Intensi Kewirausahaan Sosial Mahasiswa Program Studi Administrasi Bisnis
}

\author{
Ivon Sandya Sari Putri* \\ Jurusan Administrasi Niaga, Politeknik Negeri Bandung, Indonesia
}

\begin{abstract}
:
Social entrepreneurship is kind of business process that creates product or services which needed by society and/or environment and one of the solution to help the government to solve many kinds of social problems such as health, education, and environment problems. The purpose of this research is to identify the degree of social entrepreneurship intention of student in business administration program. The questionnaire is distributed to 100 respondents. The result shows that the intention of social entrepreneurship from students in business administration program is high $(M=3.6)$. The personal characteristics that support the social entrepreneur such as agreeableness, openness, conscientiousness and extraversion has higher degree than other personal characteristics. Those characteristics have positive impact to the social entrepreneurship intention of students in business administration program.
\end{abstract}

Keywords: social entrepreneurship, personality traits, business administration student

\section{PENDAHULUAN}

Salah satu profil lulusan dari mahasiswa Program Studi Administrasi Bisnis Politeknik Negeri Bandung adalah menjadi seorang wirausaha yang inovatif. Untuk mencapai hal tersebut maka diberikan pendidikan mengenai kewirausahaan dalam hampir setiap semesternya. Akan tetapi, bila melihat proses pembelajaran kewirausahaan selama ini, proyek bisnis yang berlangsung selalu berorientasi pada keuntungan material semata, belum terlihat adanya proses bisnis yang memberikan nilai lebih pada keadaan sosial di sekitar. Alangkah lebih baik apabila dalam setiap proyek bisnis tersebut diselipkan makna mengenai kewirausahaan sosial dimana profit tetap didapatkan tetapi juga menambah nilai dengan membantu mengatasi permasalahan sosial masyarakat sekitar.

Kewirausahaan sosial sendiri adalah kegiatan wirausaha yang dilakukan tidak

*Email korespondensi:

ivon.sandya@polban.ac.id hanya untuk memaksimalkan keuntungan tetapi juga untuk mengatasi permasalahan sosial di masyarakat dengan inovasi-inovasi yang dibentuk oleh individu ataupun kelompok. Sebagai contoh, dalam permasalahan pertanian khususnya bawang, tingginya permintaan pasar tidak diikuti dengan meningkatnya kesejahteraan petani. Para penjual membeli bawang dengan harga rendah dari petani, kemudian melewati tengkulak atau spekulan sehingga harga barang melonjak ketika di tangan konsumen. Melihat hal tersebut, terdapat sekelompok pemuda yang merancang aplikasi mobile yang bernama limakilo yang memfasilitasi pembeli tingkat rumah tangga untuk dapat membeli bawang merah langsung dari petani secara eceran maupun partai besar. Sedangkan untuk pembeli partai besar seperti rumah makan, disediakan sistem lelang dimana setiap petani dapat menentukan harga jual sendiri sehingga dapat bersaing memberikan harga termurah tanpa adanya campur tangan tengkulak. Pemerintah pun 
mendapatkan manfaat melalui aplikasi dimana pemerintah dapat mengumpulkan data harga bawang yang dapat menjadi salah satu patokan untuk memantau harga komoditas ini. Limakilo telah menggandeng Gabungan Kelompok Tani Kabupaten Brebes, Jawa Tengah untuk lebih bisa menyempurnakan aplikasi ini.

Melihat kebermanfaatan dari kewirausahaan sosial seperti contoh diatas, diharapkan akan muncul tim lain khususnya dari mahasiswa Program Studi Administrasi Bisnis Politeknik Negeri Bandung yang telah terlatih dan tertanam pendidikan mengenai kewirausahaan. Untuk mencapai hal tersebut, sebagai permulaan diperlukan adanya intensi dari para mahasiswa untuk bisa menjadi wirausaha sosial. Intensi wirausaha sosial inilah yang sebenarnya belum teridentifikasi dalam proses pembelajaran kewirausahaan selama ini. Intensi kewirausahaan sosial inilah yang akan menggerakan setiap pemikiran dan aksi bisnis mahasiswa yang berorientasi dalam inovasi pemecahan masalah sosial. Oleh karenanya diharapkan penelitian ini dapat mengidentifikasi bagaimana tingkat intensi wirausaha sosial dalam diri para mahasiswa, sehingga nantinya dapat dijadikan sebagai sumber referensi untuk mengembangkan pembelajaran kewirausahaan sosial.

\section{KAJIAN LITERATUR Kewirausahaan Sosial}

Kewirausahaan sosial adalah bagian dari kewirausahaan pada umumnya yang mengidentifikasi secara spesifik masalah sosial dan solusi untuk mengatasinya dengan menggunakan pendekatan yang inovatif melalui pembangunan bisnis yang berkelanjutan (Mair et.al., 2006; Dhesi, 2010). Kewirausahaan sosial juga dapat diartikan sebagai seorang individu, organisasi atau sebuah inisiasi dalam kegiatan kewirausahaan dengan target sosial (Baco et.al., 2013). Seorang wirausaha sosial adalah mereka yang mempunyai aktifitas untuk mencari dan mengeksplor kesempatan yang ada di lingkungan mereka untuk mendukung kesejahteraan sosial dengan membuat sebuah bisnis atau menjalankan sebuah organisasi dengan inovatif (Zahra et.al., 2009).

\section{Intensi Kewirausahaan Sosial}

Intensi adalah salah satu prediktor terbaik dalam segala perilaku yang terencana, termasuk dalam kewirausahaan (Krueger \& Carsrud, 2000). Menurut Bird (1988), intensi kewirausahaan adalah sebuah dasar pemikiran yang menunjukkan dan mengarahkan aksi wirausaha dalam pengembangan dan implementasi konsep bisnis. Peng et.al. (2012) menambahkan bahwa intensi kewirausahaan yang dimiliki oleh seseorang terdapat harapan dan keinginan yang mempengaruhi aksi kewirausahaannya. Serupa dengan pengertian intensi kewirausahaan diatas, intensi kewirausahaan sosial dapat diartikan sebagai pemikiran, keyakinan, harapan dan keinginan seorang untuk membentuk sebuah usaha berorientasi sosial (Tran \& Korflesch, 2016).

\section{Personality Trait}

Personality atau kepribadian didefinisikan sebagai proses dan perilaku yang konsisten dalam diri seseorang yang membentuk pola tetap pada individu tersebut yang mengintegerasikan tingkat emosional, kognitif, serta sikap (Burger, 2011; Mount et.al., 2005). Kepribadian seseorang memerankan peranan yang penting ketika menghadapi situasi yang kompleks dan tidak ada kepastian seperti kewirausahaan, terutama pada masa memulai (Frank et.al., 2007). Teori kepribadian yang paling banyak diadopsi adalah Big Five Personality Model yang diperkenalkan oleh Paul Costa dan Robert McRae pada tahun 1985, yang terdiri dari lima faktor yaitu agreeableness, conscientiousness, extraversion, neuroticism dan openness (Burger, 2011). 


\section{METODE}

\section{Populasi dan Sampel}

Populasi dari penelitian adalah mahasiswa Program Studi Administrasi Bisnis Politeknik Negeri Bandung baik pada program Diploma III maupun Diploma IV. Sampel dalam penelitian ini diambil menggunakan teknik purposive sampling, yang terdiri dari mahasiswa Program Studi Administrasi Bisnis yang telah mendapatkan pembelajaran atau mata kuliah yang berhubungan dengan tema kewirausahaan.

\section{Instrumen Penelitian}

Instrumen penelitian yang digunakan untuk penelitian ini berupa kuesioner yang terdiri atas tiga bagian. Bagian pertama adalah data yang diperlukan untuk mengetahui informasi profil responden yaitu jenis kelamin, usia, tingkat kelas dan domisili. Bagian kedua berisikan pernyataan untuk mengetahui bagaimana personaliti responden menggunakan teori Big Five Personality yang mengukur tingkat extraversion $(\alpha=.708 ; 5$ pernyataan $)$, neuroticism $\quad(\alpha=675 ; 5$ pernyataan $)$, openness $(\alpha=.674 ; 2$ pernyataan $)$, agreeableness ( $\alpha=399 ; 2$ pernyataan), dan conscientiousness ( $\alpha=.427 ; 5$ pernyataan). Kemudian di bagian ketiga terdapat 8 pernyataan untuk mengukur sejauh mana intensi kewirusahaan sosial $(\alpha=.894)$ responden. Penilaian kuesioner ini diukur menggunakan skala Likert 1 sampai 5 yang disesuaikan dengan jenis pernyataan sehingga memungkinkan responden untuk memilih jawaban sesuai dengan apa yang mereka rasakan.

\section{HASIL DAN PEMBAHASAN}

\section{Hasil Analisis Data}

Dilihat dari sebaran responden, sebagian besar responden adalah perempuan (75\%) karena pada Program Studi Administrasi Bisnis tercatat lebih banyak jumlah mahasiswa perempuan dibandingkan laki-laki. Rentang usia responden adalah 18 23 tahun yang merupakan usia wajar untuk mahasiswa tingkat 3 dan 4 di Program Studi Administrasi Bisnis.

Tabel 1. Profil Responden

\begin{tabular}{c|c|c}
\hline \multicolumn{2}{c|}{ Profil Responden } & Frekuensi \\
\hline Jenis & Perempuan & 75 \\
Kelamin & Laki-laki & 26 \\
\hline \multirow{4}{*}{ Usia } & $<=17$ tahun & - \\
& $18-20$ tahun & 68 \\
& $21-23$ tahun & 33 \\
& $>23$ tahun & - \\
\hline \multirow{4}{*}{ Kelas/ } & 1 & - \\
Tingkat & 2 & - \\
& 3 & 80 \\
& 4 & 21 \\
\hline \multirow{5}{*}{ Domisili } & Bandung dan & 70 \\
& sekitarnya & \\
& Sukabumi & 6 \\
& Garut & 5 \\
& Tasikmalaya & 3 \\
& Lainnya & 17 \\
\hline
\end{tabular}

Dari data yang didapatkan sebanyak 101 data responden, didapatkan hasil bahwa secara umum, mahasiswa Program Studi Administrasi Bisnis mempunyai tingkat karakteristik agreeableness ( $\mathrm{M}=3.62)$ yang lebih tinggi dibandingkan karakteristik lainnya seperti openness $(\mathrm{M}=3.35)$, extraversion $(\mathrm{M}=3.23)$, conscientiousness $(\mathrm{M}=3.22)$ dan neuroticism $(\mathrm{M}=3.15)$.

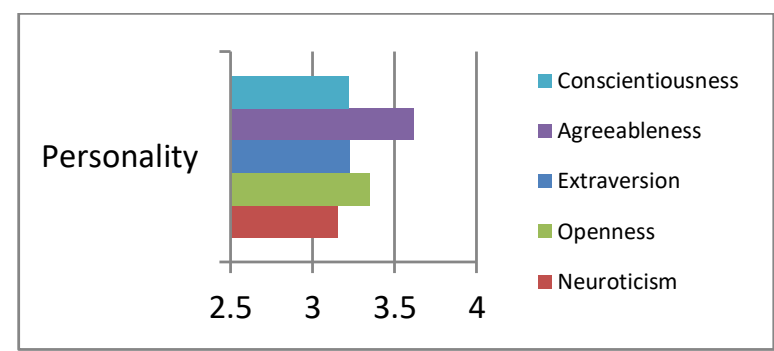

Gambar 1. Tingkat Personality Trait Responden

Tingkat intensi kewirausahaan sosial mahasiswa Program Studi Administrasi Bisnis secara umum cukup tinggi $(M=3.6)$, artinya para responden mempunyai intensi dan berkeinginan cukup kuat untuk bisa menjadi wirausaha sosial di masa yang akan datang. 
Intensi kewirausahaan sosial dipengaruhi secara positif oleh karakteristik openness $\quad(\beta=.518, \quad$ sig=.000 $) \quad$ dan extraversion $(\beta=.288$, sig $=.007)$. Intensi kewirausahaan sosial juga dapat dipengaruhi oleh karakteristik seperti agreeableness $(\beta=.465$, sig $=.011)$ dan conscientiousness $(\beta=.350, \operatorname{sig}=.011)$. Intensi kewirausahaan sosial mahasiswa Program Studi Administrasi Bisnis, paling besar dipengaruhi oleh karakteristik openness $\left(\mathrm{R}^{2}=.375\right)$.

Tabel 2. Analisis Regresi Big Five Personality terhadap Intensi Kewirausahaan Sosial

\begin{tabular}{|l|c|c|c|}
\hline \multirow{2}{*}{$\begin{array}{l}\text { Big Five } \\
\text { Personality }\end{array}$} & \multicolumn{3}{|c|}{ Intensi } \\
\cline { 2 - 4 } & Kewirausahaan Sosial \\
\hline & $\boldsymbol{\Delta}$ & $\mathbf{\Delta R}^{\mathbf{2}}$ & $\mathbf{R}^{\mathbf{2}}$ \\
\hline Extraversion & $.288^{* *}$ & & \\
Neuroticism & -.152 & .073 & .270 \\
Openness & $.518^{* * *}$ & .140 & .155 \\
Agreeableness & $.465^{*}$ & .064 & .254 \\
Conscientiousness & $.350^{*}$ & .064 & .253 \\
\hline
\end{tabular}

\section{Pembahasan}

Berdasarkan hasil analisis data, mahasiswa Program Studi Administrasi Bisnis Politeknik Negeri Bandung secara umum mempunyai tingkat sifat extraversion yang cukup tinggi. Hal tersebut dapat diindikasikan dengan ciri mahasiswa Program Studi Administrasi Bisnis POLBAN yang mudah bergaul dengan orang lain, senang dalam diskusi kelompok, dan tidak terganggu bila disekitar mereka terdapat banyak orang. Seseorang yang mempunyai sifat senang dalam berdiskusi kelompok dapat dikatakan bahwa mereka aktif dan mempunyai kemampuan komunikasi yang baik dengan orang lain. Sifat tersebut cocok untuk bisa menjadi seorang wirausaha sosial seperti apa yang telah dikemukakan oleh Crant (1996), bahwa orang yang mempunyai karakteristik extraversion adalah orang yang proaktif dan penuh dengan ide-ide serta dapat mengarahkan visi yang karismatik dari seorang wirausaha sosial. Begitupun dengan pendapat Nga \& Shamugathan (2010) yang menyatakan bahwa wirausaha sosial diharapkan mempunyai karakteristik ini karena mereka harus mau dan bisa untuk berkomunikasi dengan baik dengan banyaknya stakeholders. Nordvik \& Brovold (1998) menambahkan bahwa seorang wirausaha mempunyai tingkat extraversion yang lebih tinggi dibandingkan dengan pekerja administrasi bahkan manager dan karakteristik ini mendukung kesuksesan mereka dalam berwirausaha karena sifat mudah beradaptasi yang mereka miliki (Caliendo \& Kritikos, 2008).

Seorang wirausaha sosial selalu ingin menyelesaikan masalah-masalah yang sudah ada di benak mereka. Untuk dapat menyelesaikan masalah tersebut, diperlukan komunikasi untuk menjalin bantuan orang lain. Dengan demikian, seorang wirausaha sosial seharusnya mempunyai sifat extraversion yang tinggi. Sangatlah penting bagi seorang wirausaha sosial untuk terjun kepada aktifitas-aktifitas yang memerlukan kemampuan sosial yang tinggi seperti contohnya dalam aktifitas pembentukan kelompok untuk menyelesaikan sebuah project dan mencari sponsor. Sifat extraversion seseorang dapat dimanfaatkan untuk membuat sosial networks, menggunakannya secara efektif dan efisien untuk dapat menunjang aktifitas dari sebuah perusahaan sosial, mencari volunteer untuk bekerja pada sebuah project dan lebih lagi menjalin hubungan kerjasama dengan bisnis sosial lainnya. (Irengun \& Arikboga, 2015).

Dalam karakteristik neuroticism, mahasiswa Program Studi Administrasi Bisnis menunjukkan respon bahwa mereka cukup cemas akan berbagai hal, mudah terbawa emosi, mudah stress dan sering merasakan mood yang sering berubah. Hal ini tentu saja tidak baik bagi seorang wirausaha sosial. Kewirausahaan sosial merupakan sebuah bisnis dengan orientasi sosial, bukan berorientasi pada profit, namun nilai keuangan dapat menjadi pertimbangan untuk digunakan sebagai target yang dapat 
menyelesaikan permasalahan sosial. Dibandingkan dengan kewirausahaan konvensional, kewirausahaan sosial membutuhkan waktu yang lebih lama untuk bisa menghasilkan nilai keuangan yang baik, sehingga diprediksi bahwa seorang wirausaha sosial memerlukan sifat sabar dalam hal ini. Seperti halnya yang disampaikan oleh D'Intino, et.al.(2007) bahwa diperlukan optimism dan kecerdasan emosional yang baik untuk bisa menghadapi tekanan dari berbagai pemangku kepentingan dalam sebuah kewirausahaan.

Selain itu, mahasiswa Program Studi Administrasi Bisnis Politeknik Negeri Bandung juga mempunyai tingkat sifat openness yang cukup tinggi. Hal tersebut dapat dilihat dari mereka yang tertarik akan banyak hal baru dan penuh dengan ide-ide. Hal tersebut dibutuhkan oleh seorang wirausaha sosial, dimana menurut Nordvik \& Brovold (1998), dibutuhkan orang dengan ide-ide yang banyak untuk bisa berkreasi dalam memanfaatkan sumber daya yang terbatas yang biasanya dihadapi oleh seorang wirausaha sosial. Ketertarikan akan banyak hal baru dalam sifat openness ini berhubungan dengan kemampuan mengambil resiko. Kemampuan tersebut merupakan salah satu kemampuan yang fundamental untuk seorang wirausaha sosial. Dikarenakan orang yang mempunyai sifat terbuka biasanya senang dalam berpetualang dan berinovasi, mereka dapat dengan sukses mengidentifikasi permasalahan sosial yang ada dan dapat menemukan sumber daya untuk kegiatan sosial dan dapat turut serta dalam kegiatan sosial jangka pendek. (Irengun \& Arikboga, 2015).

Karakteristik atau sifat paling menonjol dari mahasiwa Program Studi Administrasi Bisnis pada umumnya adalah agreeableness. Mereka mempunyai rasa saling percaya terhadap sesama yang tinggi. Karakteristik agreeableness dalam sebuah hubungan interpersonal bersangkutan dengan kemampuan untuk bisa menjadi pendengar yang baik, sabar, empati dan dapat menciptakan harmoni dalam sebuah interaksi sosial (Caliendo \& Kritikos, 2008). Seperti halnya yang dikatakan oleh Irengun \& Arikboga (2015), pihak-pihak yang terlibat sebagai wirausaha sosial seharusnya memiliki tingkat empati terhadap orangorang sekitar yang membutuhkan atau mempunyai masalah, hingga mereka ingin membantu dalam menyelesaikan permasalahan tersebut. Oleh karenanya, sifat agreeableness menjadi karakteristik yang penting untuk dimiliki oleh wirausaha sosial.

Selanjutnya, sifat conscientiousness pada mahasiswa Program Studi Administrasi Bisnis juga cukup tinggi. Mereka dapat menyelesaikan tugas dengan baik, memperhatikan hal-hal secara rinci, dan menjalankan tugas tepat waktu. Dalam sebuah lingkungan kerja, sifat ini cocok untuk bisa membantu sebuah perusahaan mencapai tujuannya dengan baik karena pada dasarnya orang dengan sifat conscientiousness yang tinggi patuh pada setiap prosedur dan instruksi yang ada (Irengun \& Arikboga, 2015). Sedangkan dilihat dari intensi kewirausahaan sosial sendiri, secara umum mahasiswa Program Studi Administrasi Bisnis mempunyai intensi yang cukup tinggi dalam berkewirausahaan sosial, terutama untuk kelompok dari kelas Program Studi D-III Administrasi Bisnis-A. Dari hasil analisis data, rata-rata para responden menyatakan cukup siap untuk melakukan apapun untuk menjadi seorang wirausaha sosial dan mereka tidak ragu untuk memulai menjadi wirausaha sosial di masa depan.

Personality trait seperti extraversion, openness, agreeableness dan conscientiousness mempengaruhi intensi kewirausahaan sosial pada mahasiswa Program Studi Administrasi Niaga Politeknik Negeri Bandung. Hal ini juga sejalan dengan Nga \& Shamuganathan (2010) yang dalam penelitiannya memperlihatkan bahwa personality traits seperti agreeableness, openness dan conscientiousness mempunyai pengaruh dalam dimensi kewirausahaan 
sosial. Secara spesifik, agreeableness mempunyai hubungan positif untuk dimensi kewirausahaan sosial seperti visi sosial, inovasi, ketahanan, sosial networking dan pengembalian finansial. Wirausaha sosial secara alamiah focus untuk menyelesaikan permasalahan orang lain. Sesuatu hal yang berkaitan dengan profit-oriented sangat bertentangan dengan wirausaha sosial. Seorang wirausaha sosial diprediksi mempunya tingkat neuroticism yang rendah. Menjadi seorang wirausaha sosial akan menemukan banyak masalah, untuk itu orang yang mempunyai emosi yang stabil akan lebih sukses untuk bisa mendirikan dan menjalankan sebuah sosial enterprise dan dapat menjaga hubungan eksternal dengan baik.

\section{KESIMPULAN DAN SARAN Kesimpulan}

Berdasarkan dari hasil analisis dan pembahasan yang telah diuraikan pada bagian sebelumnya, maka dapat ditarik kesimpulan:

1. Intensi kewirausahaan sosial mahasiswa Program Studi Administrasi Bisnis secara umum cukup tinggi. Secara spesifik, mahasiswa Program Studi D-III Administrasi Bisnis mempunyai tingkat intensi kewirausahaan sosial yang lebih tinggi dibandingkan dengan mahasiwa Program Studi D-IV Administrasi Bisnis.

2. Personality trait seperti extraversion, openness, agreeableness dan conscientiousness mempunyai pengaruh terhadap intensi kewirausahaan sosial pada mahasiswa Program Studi Administrasi Bisnis Politeknik Negeri Bandung.

\section{Saran}

Mengingat kewirausahaan sosial menjadi salah satu cara untuk dapat membantu menyelesaikan masalah sosial di masyarakat saat ini, alangkah lebih baik bila sebagai pendidikan vokasi yang lebih memfokuskan diri pada pendidikan praktis untuk menyelesaikan masalah, institusi dapat memberikan kontribusi untuk membina dan melatih para mahasiswa terutama mahasiswa pada Program Studi Administrasi Bisnis Jurusan Administrasi Niaga Politeknik Negeri Bandung untuk memberikan nilai lebih ketika para mahasiswa mempelajari tentang mata kuliah kewirausahaan sebagai mata kuliah wajib saat ini.

Institusi dapat menyiapkan modul bahan ajar khusus mengenai kewirausahaan sosial pada setiap mata kuliah yang berhubungan dengan kewirausahaan. Sehingga mahasiswa Program Studi Administrasi Bisnis dengan profil lulusan yang dapat menjadi seorang wirausaha mandiri, juga dapat ikut berkontribusi dalam menyelesaikan permasalah sosial di masyarakat dengan bisnis sosial yang didirikannya. Penelitian ini juga dapat memberikan gambaran diperlukannya pelatihan mengenai karakteristik personal kepada mahasiswa sejak dini sehingga para mahasiswa mempunyai karakteristik yang siap untuk bisa menjadi seorang wirausaha.

\section{DAFTAR PUSTAKA}

Baco, S., Hartog, C., \& Hoogendoorn, B. (2013). A Quantitative Comparison of Social and Commercial Entrepreneurship: Toward a More Nuanced Understanding of Social Entrepreneurship Organizations In Context. Journal of Social Entrepreneurship, 4(1), 40-68.

Bird, B. (1988). Implementing entrepreneurial ideas: the case for intention. The Academy of Management Review, 13(3), 442-453.

Burger, J. (2011). Personality. Belmount: Cengage Learning.

Caliendo, M., \& Kritikos, A. (2008). Is entrepreneurial success predictable? An Ex-ante analysis of the characterbased approach. Kyklos, 189-214.

Crant, J. (1996). The proactive personality scale as a predictor of entrepreneurial 
intentions. Journal of Small Business Management, 42-49.

Dees, J. (1998). The Meaning Of Social Entrepreneurship. Stanford: Stanford University.

Dhesi, A. (2010). Diaspora, Social Entrepreneurs, and Community Development. International Journal of Social and Economic, 37(9), 703716.

D'Intino, R., Goldsby, M., Houghton, J., \& Neck, C. (2007). Self leadership: A process for entrepreneurial success. Journal of Leadership \& Organizational Studies, 105-120.

Frank, H., Lueger, M., \& Korunka, C. (2007). The significance of personality in business start-up intentions, start-up realization and business success. Entrepreneurship \& Regional Development, 227-251.

Irengun, O., \& Arikboga, S. (2015). The effect of personality traits on social entrepreneurship intentions: A field research. Social and Behavioral Sciences, 1186-1195.

Krueger, N. (2000). Competing models of entrepreneurial intentions. Journal of Business Venturing, 15(5), 411-432.

Llewellyn, D., \& Wilson, K. (2003). The controversial role of personality traits in entrepreneurial psychology. Education and Training, 341-345.

Mair, J., Robinson, J., \& Hockrets, K. (2006). Social Entrepreneurship. New York: Palgrave Macmillan.
Mount, M., \& Barrick, M. (2005). Higherorder dimensions of the big five personality traits. Personnel Psychology, 447-478.

Nga, J. K., \& Shamuganathan, G. (2010). The influence of Personality Traits and Demographic Factors on Social Entrepreneurship Start Up Intentions. Journal of Business Ethics, 259-282.

Nordvik, H., \& Brovold, H. (1998). Personality traits in leadership tasks. Scandinavian Journal of Psychology, 61-64.

Peng, Z., Lu, G., \& Kang, H. (2012). Entrepreneurial intentions and its influencing factors: A survey of the university students in Xi'an China. Creative Education, 3(8), 95-100.

Sugiama. (2008). Metode Riset Bisnis dan Manajemen. Bandung: Guardaya Intimarta.

Sugiyono. (2012). Metode Penelitian Kuantitatif dan Kualitatif $R \& D$. Bandung: Alfabeta.

Tran, A., \& Korflesch, H. (2016). A conceptual model of social entrepreneurial intention based on the social cognitive career theory. Asia Pasific Journal of Innovation and Entrepreneurship, 10(1), 17-38.

Zahra, S., Gedajlovic, E., Neubaum, D., \& Shulman, J. (2009). A Typology Of Social Entrepreneurs: Motives, Search Processess and Ethical Challenges. Journal of Business Venturing, 24(5), 519-532. 